\title{
Delayed Breast Reconstruction with Latissimus Dorsi Myocutaneous Flap and Implant in Patients Undergoing Total Mastectomy
}

\section{Total Mastektomi Yapılan Hastalarda Latissimus Dorsi Kas Deri Flebi ve İmplant ile Geç Dönem Meme Rekonstrüksiyonu}

\author{
Yahya Baltu ${ }^{1}$, Orhan Aydın ${ }^{1}$ \\ Ankara Oncology Training and Research Hospital, Dept. of Plastic Surgery, Ankara, TURKEY
}

Dergiye Ulaşma Tarihi: 23.02.2018 Dergiye Kabul Tarihi: 11.03.2018 Doi: 10.5505/aot.2018.82788

\section{ÖZET}

GíRiş ve AMAÇ: Bu çalışmamızda total mastektomi uygulanan hastalarda latissimus dorsi kas deri flebi + implant ile geç dönem meme rekonstrüksiyonu yapılan hastalar incelenip estetik sonuçların ve komplikasyonların değerlendirilmesi amaçlanmıştır.

YÖNTEM ve GEREÇLER: $\mathrm{Bu}$ çalışmaya latissimus dorsi kas-deri flebi ve implant ile geç dönem rekonstrüksiyon uygulanan total mastektomili hastalar dahil edildi.

BULGULAR: 2013-2018 yılları arasında toplam 24 hasta ve 25 total mastektomi uygulanmış memeye geç dönemde latissimus dorsi kas-deri flebi + implant ile rekonstrüksiyon uygulandı. Tüm kadın hastaların yaş ortalaması 44.0 olarak hesaplandı. 12 sağ meme ve 13 sol memeye rekonstrüksiyon uygulandı. Ameliyat süresi 135 ile 220 dakika arasında not edildi. Post-operatif olarak hiçbir hastada kısmi ya da total flep nekrozu görülmedi. Enfeksiyon, implant protuzyonu veya rüptürü, hematom veya keloid hiçbir hastada görülmedi. 4 hastada 1 ay kadar süren ve aspirasyon ile düzelen seroma gelişti. 1 hastada 2. ayda meme dokusu üzerinde selülit benzeri bir görünüm mevcuttu. 1 hafta IV antibiyotik tedavisi ile düzelme sağlandı. Donör alanda sadece 3 hastada tatmin edici olmayan skar ile karşılaşıld. Hiçbir hastada meme alanında kötü skar görülmedi. Rekonstrükte edilen memeler için ortalama 255 (175-300) cc yuvarlak silikon jel implant kullanıldı.

TARTIŞMA ve SONUÇ: Latissimus dorsi kas-deri flebi geç dönem meme rekonstrüksiyonu için son derece güvenli ve muteber bir seçenektir. Özellikle ameliyat sonrası komplikasyonlardan çekinen ve en kısa sürede normal hayatına dönmek isteyen hastalar için diğer rekonstrüktif yöntemlere göre basit ve komplikasyonları az bir yöntemdir.

Anahtar Kelimeler: Geç dönem meme rekonstrüksiyonu; latissimus dorsi; implant; mastektomi

\begin{abstract}
INTRODUCTION: In this study, we aimed to investigate the aesthetic outcomes and complications of delayed breast reconstruction with latissimus dorsi myocutaneous flap + implant among patients undergoing total mastectomy operation.
\end{abstract}

MATERIAL and METHODS: This study included patients operated with latissimus dorsi myocutaneous flap+implant after total mastectomy operation.

Results: We performed delayed reconstruction with Latissimus Dorsi myocutaneous flap+implant for 24 patients and 25 total mastectomized breasts between 2014 and 2018. The study population had a mean age of 44.0 years. Twelve right and 13 left breasts were reconstructed. Operative time ranged between 135 and 220 minutes. None of the patients suffered partial or total flap necrosis, infection, implant protrusion or rupture, or keloid formation. Four patients developed seroma lasting for up to 1 month, which improved upon aspiration. One patient developed a cellulitis-like appearance on the breast tissue at the second month, which improved after a 1-week course of IV antibiotics. Only three patients had a bad scar formation at the donor site. No patient had bad scar formation in the mammary region. The median volume of round implants was 250 (175-300) ml. None of the patients suffered cancer recurrence.

DISCUSSION and CONCLUSION: Latissimus dorsi myocutaneous flap + implant procedure is an extremely safe and reliable option for delayed breast reconstruction. It is a simple technique with less complications than other reconstructive techniques, particularly for patients who fear postoperative complications and who wish to return to normal life.

Key Words: Delayed breast reconstruction; latissimus dorsi; implant; mastectomy 


\section{INTRODUCTION}

Breast cancer is the most prevalent invasive cancer among women, constituting $16 \%$ of all cancers and $22.9 \%$ of all invasive cancers among women. Additionally, it is responsible for $14 \%$ of cancer-related deaths among women (1-3).

The number of women demanding breast reconstruction has been gradually increasing. An ideal breast reconstruction method should be safe and reliable, associated with less donor site morbidity, and provide adequate volume, shape and size in the reconstructed breast. In the last decade breast reconstruction has not only aimed to get a satisfactory breast image, but also to provide an aesthetic look, contour, volume, shape, nipple-areolar complex reconstruction, fullness in the lower breast pole, and symmetry with the contralateral breast (4-8).

In this study we reviewed the medical records of women who underwent delayed breast reconstruction with latissimus dorsi myocutaneous (LD) flap following total mastectomy operation in order to assess the operation's aesthetic outcomes and complications.

\section{MATERIALS and METHODS}

This study included patients operated with LD flap + implant after total mastectomy operation between 2014 and 2018. Operation time, age, side, and complications were recorded. Type, size, and shape of the implant used reported as well. While some patients had their contralateral breast intervened at the same session, some others had their asymmetry corrected at a second session when a nipple was reconstructed.

\section{Surgical technique:}

All procedures were performed under general anesthesia. Starting from the lateral decubitus position, the old incision scar tissue was excised and the recipient area was prepared through this incision. Skin flaps were raised, and a breast space was formed. Latissimus dorsi muscle was localized from its borders and marked between the medial midline, posterior axillary line, iliac crest laterally, and the tip of scapula inferiorly.
A skin island was drawn with the Pinch move depending on skin elasticity, so that the final wound scar would be hidden either on the bra line or oblique scapular line. Musculocutaneous flap was explored from the serratus muscle on the lateral side and trapezius muscle on the medial side. The flap's pedicle was dissected towards axilla, and the flap was raised with care to preserve thoracodorsal artery and vein. After creating a subcutaneous tunnel between the donor site and breast in the axillary region, the flap was transferred anteriorly to the breast region. After achieving hemostasis, a closed suction drain was placed into the donor site and the surgical field was closed with appropriate sutures. The patient was then brought to supine position. Latissimus dorsi muscle was sewn to the rectus fascia inferiorly. An appropriatelysized implant sizer fitting into latissimus dorsi flap without excess retention was proved, and an appropriate permanent round shaped cohesive silicone gel implant was placed. A negative-pressure hemovac drain was placed into the surgical field. The muscle was sutured all around the implant, and skin and subcutaneous tissue were sutured with twolayered sutures.

\section{RESULTS}

We performed delayed reconstruction with LD flap + implant for 24 patients and 25 total mastectomized breasts between 2014 and 2018. The study population had a mean age of 44.0 years (34-58 years). Twelve right and 13 left breasts were reconstructed. Operative time ranged between 135 and 220 minutes. None of the patients suffered partial or total flap necrosis, infection, implant protrusion or rupture, hematoma, or keloid formation at the surgical site. Four patients developed seroma lasting for up to 1 month, which was improved by aspiration. Only three patients had an unsatisfactory scar formation at the donor site. No patient had bad scar formation in the mammary region. The median volume of round implants was 250 (175-300) cc (Figure $1,2,3)$. None of the patients suffered cancer recurrence. One patient developed a cellulitislike appearance on the breast tissue at the second month, which improved after a 1-week course of IV antibiotics. The patients 
complained of axillary bulging early in the disease course but none of them complained of bulging as they improved by 6 months. The implant of a patient was enlarged upon patient's request.

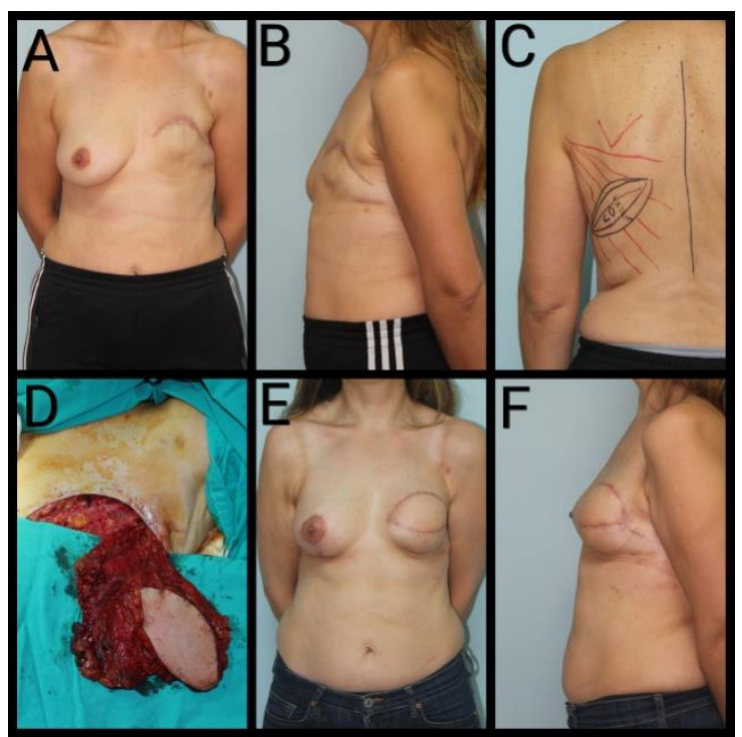

Figure 1: A 43-year-old woman who had previously undergone total mastectomy. A: Preoperative anterior view B: Preoperative lateral view. The breast reconstructed with $\mathrm{LD}$ flap +175 cc round silicone gel implant. C: The view of the flap design D: Elevation of the flap E: Postoperative 3 months view (anterior) F: Postoperative 2 months view (lateral)

\section{DISCUSSION}

Breast reconstruction can be performed as an immediate or delayed procedure. Immediate reconstruction may provide better aesthetic outcomes and, as it eliminates the sense of deformity following mastectomy, it may also benefit patients psychologically. Immediate reconstruction is also cheaper and reduces the total number of anesthesia procedures $(3,4,7)$. On the other hand, Göktaş et al reported that, as compared to delayed reconstruction, immediate reconstruction resulted in improvements in body image, self-respect, and social relations. Immediate reconstruction also reportedly reduces somatic complaints and provides psychological, social, and spritual improvements in quality of life (9). Unfortunately, immediate breast reconstruction is not feasible in every patient, mainly because of oncology physicians not recommending this procedure as a result of a higher recurrence rate of breast cancer within the first two years.

Adress for correspondence: Dept. of Plastic Surgery, Ankara Oncology Training and Research Hospital, Ankara, TURKEY e-mail: baltuyahya@gmail.com

Available at www.actaoncologicaturcica.com

Copyright $\odot$ Ankara Onkoloji Hastanesi
Some patients with breast cancer may refuse early reconstruction procedure after mastectomy as they may be psychologically unprepared for the procedure. Early reconstruction may also be postponed due to planned radiotherapy. Sometimes, delayed breast reconstruction is planned when an expander or implant that is immediately placed after mastectomy is to be removed because of complications $(10,11)$. Despite the advantages of the immediate reconstruction, it is reportedly associated with a greater complication rate than delayed reconstruction $(12,13)$. Indeed, the rate of long-term complications is high, with more than $30 \%$ of women having implants placed following mastectomy suffer complications within the first 5 years after the procedure. The most common problems are capsule contracture, implant rupture, wound infection and hematoma. Radiotherapy confers a greater risk for capsular contracture and other complications after breast reconstruction using implants (7,14-17).

Delayed breast reconstruction is defined as breast reconstructions performed at any time, excluding immediate breast reconstruction. This procedure can be achieved using autogenous tissues and/or implant. Autologous tissue transfer may remain the sole option for cases that undergo radiotherapy or have their muscles and skin affected by mastectomy operation. Furthermore, delayed breast reconstruction offers the advantage of correcting tissue injury that may occur due to wound site complications or radiation after mastectomy $(7,9,12,18,19)$.

Delayed breast reconstruction with autologous tissue can be achieved using abdominal based flaps (free or pedicled transvers rectus abdominis musclocutaneous flap (TRAM), deep inferior epigastric perforator flap (DIEP), superficialis inferor epigastic artery flap), LD flap, free gluteal flap or Rubens flap. TRAM flap is the most commonly used surgical option for breast reconstruction procedures. The advantages of TRAM flap include achieving a autogenous tissue reconstruction and a relatively acceptable scar in donor area. Contour correction can also be achieved thanks to excessive abdominal skin and fat tissue used 


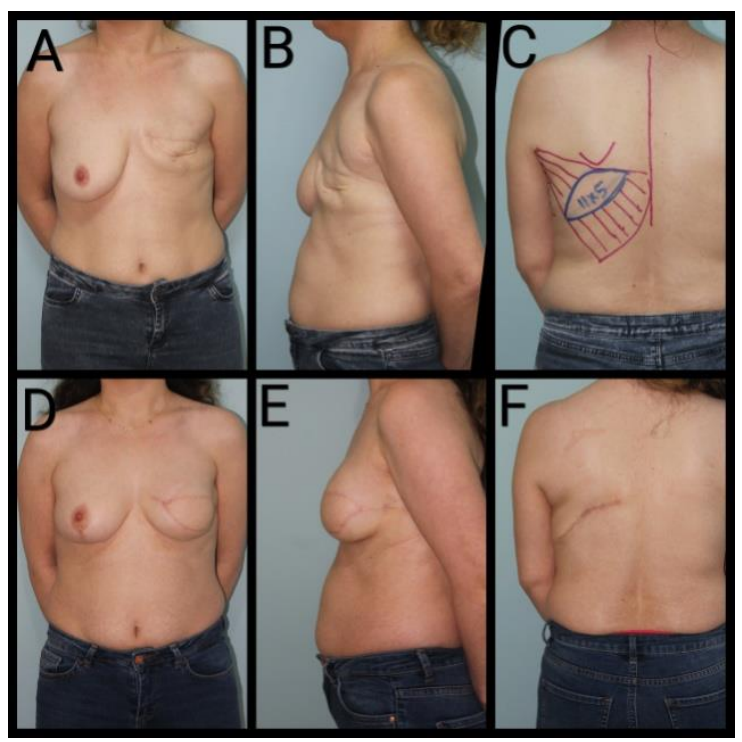

Figure 2: A 45-year-old woman who had mastectomy for breast cancer. A: Anterior preoperative view of the patient. B: Lateral preoperative view. The patient underwent reconstruction with left LD flap $+200 \mathrm{cc}$ round silicone gel implant. C: The design of LD flap. D: The photograph at $6^{\text {th }}$ month postoperatively (anterior view) E: The photograph at $6^{\text {th }}$ month postoperatively (lateral view) F: The view of the donor site at $6^{\text {th }}$ postoperatively.

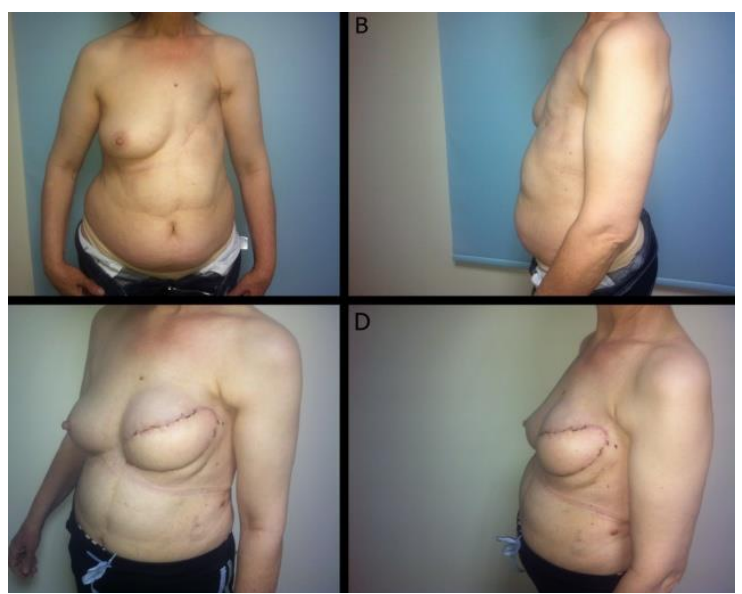

Figure 3: A 64-year-old woman who had undergone total mastectomy of the left breast 20 years ago. A: Preoperative view of the patient (anterior) B: Preoperative view (lateral). The left breast was reconstructed with left LD flap $+300 \mathrm{cc}$ round silicone gel implant. C: The view of the patient at first month postoperatively (oblige) D: The view of the patient at first month postoperatively (lateral).

for reconstruction. Its disadvantages include delayed recovery, fat necrosis, weakening of abdominal wall, bulking in the epigastric region. It results in a reduced abdominal bloating or hernia particularly with pedicled Adress for correspondence: Dept. of Plastic Surgery, Ankara Oncology Training and Research Hospital, Ankara, TURKEY e-mail: baltuyahya@gmail.com

Available at www.actaoncologicaturcica.com

Copyright $\odot$ Ankara Onkoloji Hastanesi
TRAM flap. Free TRAM and DIEP flaps have less donor area morbidity compared to pedicled TRAM flap. Nevertheless, these techniques require microsurgery experience and complications complete or partial graft loss have been reported. Moreover, donor area morbidity cannot be completely addressed with these procedures. (20-22) LD flap is a good alternative option for patients having obesity, diabetes, hypercoagulation, hypertension, and smoking history who are at high risk for TRAM flap reconstruction, or those at high risk for donor area morbidity due to previous abdominal surgery or flap complication risk $(5,12)$. LD flap provides a reliable blood flow and has advantages like minimal donor area morbidity. Its disadvantages include a donor scar area sitting on the back region, the need for repositioning patient during the surgery, and a frequent need of an implant to achieve sufficient volume. However, some breast cancer patients are avoid of postoperative complications during delayed breast reconstruction and may want to return to normal life as soon as possible. For these patients, LD flap is a simple technique and has less complications than other reconstructive techniques.

The amount of tissue needed for breast reconstruction following total mastectomy is large, and LD flap alone is not sufficient. Therefore, the use of an implant along with LD flap is usually necessary. In our study we used round shaped cohesive silicone gel implants for all reconstructed breasts because we consider that they are easier and simpler choice to reshape. Although some authors use anatomic implants, we preferred round implants due to absence of rotation-related complications. In patients undergoing radiotherapy an implant with a smaller size can fit into the breast pouch. This is because fibrosis and contracture occurring at sites treated with radiotherapy reduce skin elasticity. None of our patients experienced partial or total flap loss, infection, or implant protrusion. Our patients complained about bulging at the axillary region. However, the bulging regressed by 6 months, and none of the patients accepted surgery for this indication.

The only significant complication seen in our patients was seroma, which was improved by aspirations performed at regular 
intervals. Burgić reported seroma development in 19 of 20 (95\%) patients and a hematoma incidence of $15 \%$ (23). Despite having not placed extra anchor sutures or performed any other procedure, we observed a seroma in four $4(16 \%)$ of 25 patients. However, there was no hematoma case. We attribute the low number of seroma cases to quick elevation of myocutaneous flap and quick closure of the donor site, as well as tensionless closure of the donor site.

\section{CONCLUSION}

Latissimus dorsi myocutaneous flap + implant procedure is an extremely safe and reliable option for delayed breast reconstruction. It is a simple technique with fewer complications than other reconstructive techniques, particularly for patients who fear postoperative complications and who wish to return to normal life.

\section{Conflict of interest: none}

\section{REFERANSLAR}

1. World Health Organization. Breast cancer: prevention and control. WHO; 2012. Available online at: http://www.who.int/ cancer/detection/breastcancer/en/, accessed 16 January 2015

2. Dede İ, Çetin Ş. Survival Analysis in Breast Cancer Patients: Frailty Models. Acta Oncologica Turcica:;50(2):130-8

3. Cohen BE, Cronin ED. Breast reconstruction with the latissimus dorsi musculocutaneous flap. Clinics in plastic surgery. $1984 \mathrm{Apr} ; 11(2)$ :287-302

4. Hammond DC. Latissimus dorsi flap breast reconstruction. Clin Plast Surg. 2007;34(1):75-82

5. Kovacs L, Papadopulos NA, Ammar SA, Klöppel M, Herschbach P, Heinrich G, Baumann A, Biemer E. Clinical outcome and patients' satisfaction after simultaneous bilateral breast reconstruction with free transverse rectus abdominis muscle (TRAM) flap. Ann Plast Surg. 2004;53(3):199-204

6. Hoover SJ, Kenkel JM. Breast cancer, cancer prevention, and breast reconstruction. Select Readings Plast Surg. 2002;9(30):19

7. Galip, and O. Onur Erol. Delayed breast reconstruction with latissimus dorsi flap. Aesthet Plast Surg. 33.3 (2009): 413-20

8. Alderman AK, Wilkins EG, Kim HM, Lowery JC. Complications in postmastectomy breast reconstruction: two-year results of the Michigan Breast Reconstruction Outcome Study. Plast Reconstr Surg. 2002;109(7):2265-74

9. Göktaş SB, Güllüoğlu BM, Şelimen D. Immediate or delayed breast reconstruction after radical mastectomy in breast cancer patients: does it make a

Adress for correspondence: Dept. of Plastic Surgery, Ankara Oncology Training and Research Hospital, Ankara, TURKEY

e-mail: baltuyahya@gmail.com

Available at www.actaoncologicaturcica.com

Copyright $\odot$ Ankara Onkoloji Hastanesi difference in the quality of life. Turkiye Klinikleri J Med Sci. 2011;31(3):664-73

10. Colleoni M, Sun Z, Price KN, Karlsson P, Forbes JF, Thürlimann B, et al. Annual hazard rates of recurrence for breast cancer during 24 years of follow-up: results from the international breast cancer study group trials I to V. J Clin Oncol. 2016;34(9):927-35

11. Thamm OC, Andree C. Immediate Versus Delayed Breast Reconstruction: Evolving Concepts and Evidence Base. Clin Plast Surg. 2018;45(1):119-27

12. Sullivan SR, Fletcher DR, Isom CD, Isik FF. True incidence of all complications following immediate and delayed breast reconstruction. Plast Reconstr Surg 2008;122(1):19-28

13. Hankins CL, Friedman J. A 7-year experience in utilizing the latissimus dorsi myocutaneous flap for bilateral breastreconstruction. Ann Plast Surg. 2008;60(2):134-40

14. Gabriel SE, Woods JE, O'Fallon WM, Beard CM, Kurland LT, Melton LJ. Complications leading to surgery after breast implantation. $\mathrm{N}$ Engl $\mathrm{J}$ Med 1997;336(10):677-82

15. Behranwala KA, Dua RS, Ross GM, et al. The influence of radiotherapy on capsule formation and aesthetic outcome after immediate breast reconstruction using biodimensional anatomical expander implants. J Plast Reconstr Aesthet Surg. 2006; 59(10):1043-51

16. Percec I, Bucky LP. Successful prosthetic breast reconstruction after radiation therapy. Ann Plast Surg 2008;60(5):527-31

17. Krueger EA, Wilkins EG, Strawderman M, Cederna P, Goldfarb S, Vicini FA, et al. Complications and patient satisfaction following expander/implant breast reconstruction with and without radiotherapy. Int J Radiat Oncol Biol Phys. 2001;49(3):713-21

18. Metcalfe KA, Semple J, Quan ML, Holloway C, Wright F, Narod S, et al. Why some mastectomy patients opt to undergo delayed breast reconstruction. Plast Reconstr Surg. 2017;139(2): 267-75

19. Henry LR, Morris LL, Downs R, Schwarz RE. The impact of immediate breast reconstruction after mastectomy on time to first adjuvant treatment in women with breast cancer in a community setting. Am J Surg. 2017;213(3):534-8

20. Ducic I, Spear SL, Cuoco F, Hannan C. Safety and risk factors for breast reconstruction with pedicled transverse abdominal flaps: a 10-year analysis. Ann Plast Surg. 2005;55:559-64

21. Futter CM, Webster MH, Hagen S, Mitchell SL. A retrospective comparison of abdominal muscle strength following breast reconstruction with a free TRAM or DIEP flap. Brit J Plast Surg. 2000;53(7):578-83

22. Murphy BD, Kerrebijn I, Farhadi J, Masia J, Hofer SO. Indications and Controversies for AbdominallyBased Complete Autologous Tissue Breast Reconstruction. Clin Plast Surg. 2017;45(1):83-91

23. Burgić M, Bruant-Rodier C, Wilk A, Bodin F, Rifatbegović A, Halilbašić E, et al. Complications following autologous latissimus flap breast reconstruction. Bosn J Basic Med Sci. 2010;10(1):65 
